University of Rhode Island

DigitalCommons@URI

Open Access Master's Theses

1972

\title{
Poe's Concept of Supernal Beauty as Applied to Selected Poems
}

Robert Charles Angell

University of Rhode Island

Follow this and additional works at: https://digitalcommons.uri.edu/theses

\section{Recommended Citation}

Angell, Robert Charles, "Poe's Concept of Supernal Beauty as Applied to Selected Poems" (1972). Open Access Master's Theses. Paper 1348.

https://digitalcommons.uri.edu/theses/1348

This Thesis is brought to you for free and open access by DigitalCommons@URI. It has been accepted for inclusion in Open Access Master's Theses by an authorized administrator of DigitalCommons@URI. For more information, please contact digitalcommons-group@uri.edu. 


\section{POE'S CONCEPT OF SUPERNAL BEAUTY \\ AS APPLIED TO SELECTED POEMS \\ BY \\ ROBERT CHARLES ANGELL}

A THESIS SUBMITTED IN PARTIAL FULFILLMENT OF THE

REQUIREMENTS FOR THE DEGREE OF

MASTER OF ARTS

IN

ENGLISH

UNIVERSITY OF RHODE ISLAND

1972 


\section{MASTER OF ARTS THESIS \\ OF}

ROBERT CHARLES ANGELL

Approved:

Thesis Comittee:

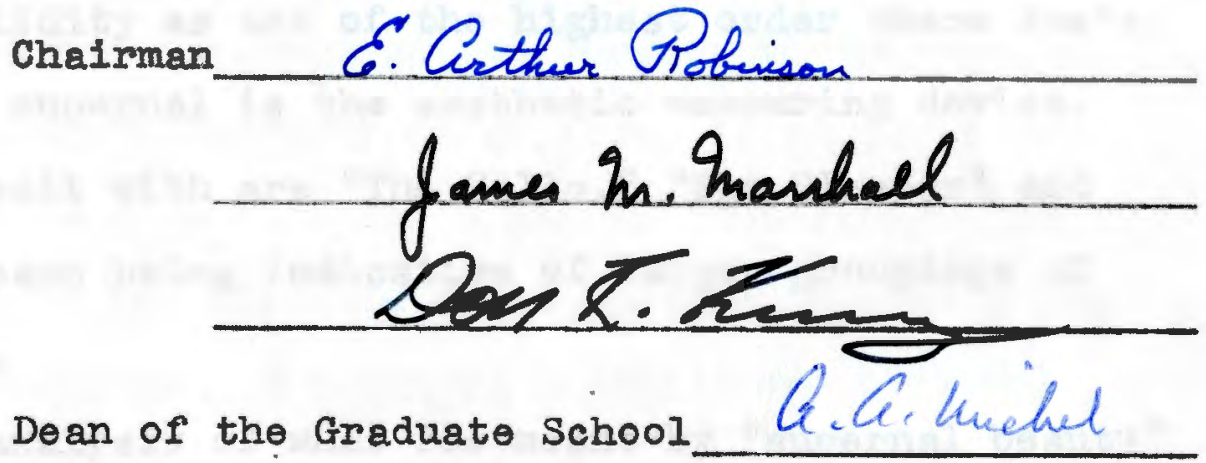

UNIVERSITY OF RHODE ISLAND

1972 


\section{ABSTRACT OF THESIS}

This thesis is primarily concerned with Edgar

Allan Poe's application of his aesthetic philosophies to his poetic writings. In particular, the extent to which the selected poems are successful in attaining or simulating the attainment of supernal beauty is examined. The ideas herein dealt with are those having to do with Poe's reaching for the ethereal world of the imagination through his art. While specific poems are analyzed with respect to his critical writings, this thesis nover assumes that his poetry was nothing save a practical exercise of those theories. The selected poems are explored with regard to their validity as art of the highest order where Poe's idea of the supernal is the aesthetic measuring device. The poems dealt with are "The Bells," "The Sleeper" and "Israfel"--each being indicative of larger groupings of Poe's poems.

An analysis of. what Poe meant by "supernal beauty" is undertaken in order to establish something of a foundation on which to construct a case for the several poems as vehicles to an appreciation of the ethereal imaginative world. By comparing the poems, and analyzing each in terms of the critical writings, an evaluation of Poe's use of artistic methods is undertaken. These methods are enumerated in Chapter II. Dealing with Poe as a completely rounded artist rather than only as a poet was rewarding 
in that it led to the formulation of the theory that an appropriate sensory focus is necessary to an understanding of the supermal state. This focus theory, based on one of the tales ("The Sphinx"), became applicable in an infinite number of places. The major contribution of this thesis Iies in the surfacing of this theory of interior focus and its relevance in the study of Poe's aesthetic philosophies as they relate to his own poetry.

It is my contention that an understanding of Poe's sensory focus must first be mastered before one may expect to understand his spiritual release into the realm of the supernally beautiful. The three major poems herein dealt with require conscientious purging of the soul before they can reasonably be expected to succeed as vehicles in the search after ethereal loveliness. The examination of the poems is based on this sort of aesthetic open-mindedness and is centered in.Poe's own critical work. 


\section{TABLE OF CONTENTS}

CHAPTER

PAGE

I. INTRODUCTION........................... I

Critical Acrimony........................ 2

Attention to the Ethereal.................. 8

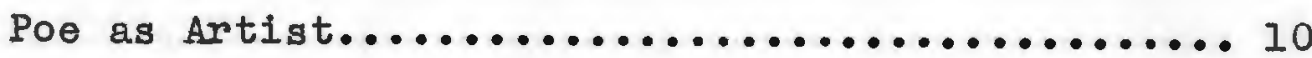

The Concept of Sensory Focus................ 13

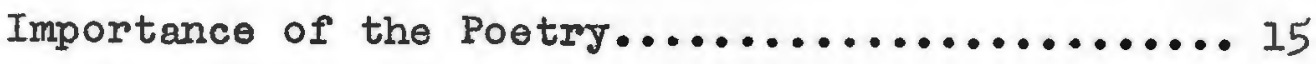

II. SUPERNAL BEAUTY......................... 17

Methods of Achieving Supernal State........... 18

Poe's Approach to the Supernal...............23

Major Characteristics..................... 29

III. THE HYPNOTIC STATE AS A ROUTE TO THE

SUPERNAL IN "THE BELLS"................ 31

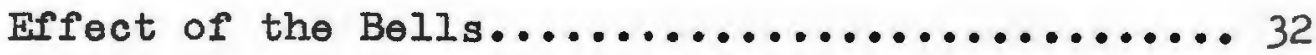

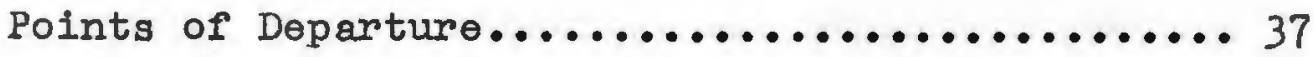

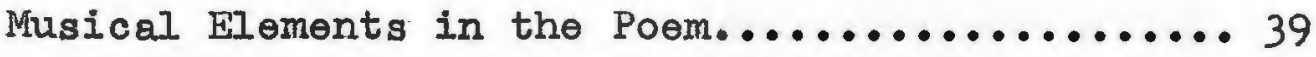

IV. "THE SLEEPER" ............................. 44

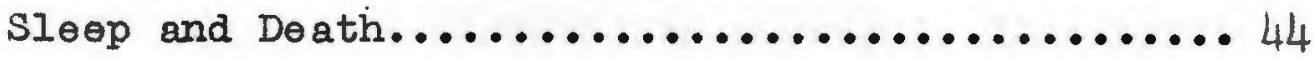

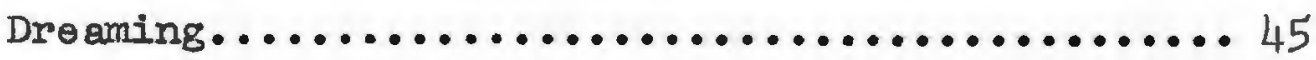

Mesmerism and Immortality of the Mind..........50

Use of Sleep in Aesthetic Quest.............. 52

V. ARTISTIC TRANSCENDENCE TO THE SUPERNAL WORLD

IN "ISRAFEL" ............................. 55

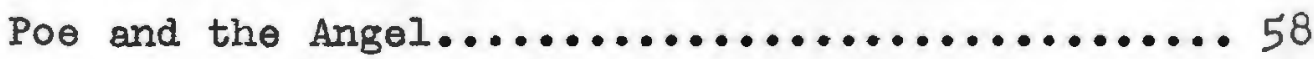

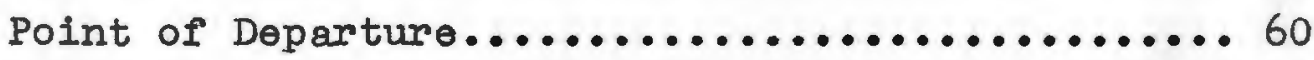


CHAPTER

PAGE

Artistic Touch.............................62

Music as an Emotional Outlet.................64

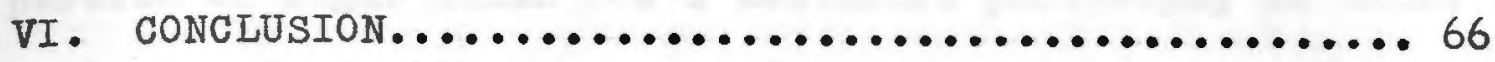

Results of Investigation......................66

VII. BIBLIOGRAPHY.......................... 70 


\section{INTRODUCTION}

The purpose of this thesis is to examine that portion of Edgar Allan Poo's aesthetic philosophy in which he is involved with the quest for supernal beauty. This area of Poe's writing has been generally overlooked by scholars who tend to deal with the tales and poems with no eye open to aesthetic gain. Often ignored as being vague, the aesthetic concept of supernal beauty aids the reader in attaining a fuller understanding of the poetry. By applying what is extracted from the critical writings to certain pooms chosen for their particular value in illuminating those theories, a concrete analysis of the supernal experience is undertaken.

The poems ("The Bells," "The sleeper" and "Israfel") were selected for their usefulness and expository nature with respect to certain aspects of Poo's foelings about supernal beauty. Each presents a different approach capable of creating the heightening effect on the soul which Poe thought necessary in the poem. The hypnotic effect of the bells, the beauty of sleep and death, and the contemplation of ethereal music are sympathetically dealt with in these three poems. To attempt an exhaustive investigation of Poe's pootry in terms of the concept of supernal beauty would be a problem of considerably larger scope than could be dealt with in a thesis of this size. The three poems analyzed are, however, indicative 
of a large number of the poems and are particularly holpful in elucidating Poo's aesthetic philosophies.

Floyd Stovall has attempted in his ow critical

writings to group the critics of Poo into six classes, each exposing its own weaknesses and strengths. Stovall is being painfully accurate when he states that, "I have no quarrel with those who dislike Poe's work so long as they understand it...I am persuaded that much of the criticism of Poe in this century, whother favorable or unfarorable, has been done by people who have not taken the trouble to understand his work."l Obviously, the reading of Poe is a good deal more difficult than the misreading of Poo. It is little wonder that the critics who failed to respond to Poo's prose work (like those dealt with later in this chapter) would likewise fail in the investigation of his verse. If we accept this bit of academic logic, we cannot fail to be delighted that his poetry has been largely ignored by these ill-equipped critical readers.

of his critics, surprisingly few have been poets themselves. Perhaps identification with the poetic extremes is necessary to fully understand Poo's literary direction. Those who have attacked his work have done so with remarkable vigor as if his gain was counted as a personal loss. Henry James is one who had mixed feelings about the

IFloyd Stovall, "The Conscious Art of Edgar Allan Poe," in Poe- A Colloction of Critical Essays, ed. by Robert Regan (Englewood CIiffs: Prentice Hali, Inc., 1967), pp. $172-74$. 
poet. Finding much to praise in The Narrative of Arthur Gordon Pym, he finds all too little in the poetry or tales. James remarked, "an enthusiasm for Poe is the mark of a decidedly primitive stage of reflection" jet grudgingly admitted in a comparison of $P \circ \theta$ and Baudelaire that Poo was "the greater genius."2

Critic W. J. Bate, writing in his introduction to an abbreviated version of "The Poetic Principle," undercuts Poe's choice of words by offering the most pedestrian of definitions for certain terms favored by Poe. He attacks Poe's use of the word "beauty," for instance, on the grounds that he (Poe) "did not really succeed in defining" the concept. This sort of remark could only have been made by the critic who could not understand Poe's treatise on beauty as contained in his critical writings. Poe, of course, did define beauty with a precision which reached nearly beyond the power of words. His concept of beauty was concerned largely with a reaching for the ethereal loveliness which he saw as existing beyond the grave. Poe's definition of supernal beauty was elucidated as thoroughly in the poetry as in the critical writings. For instance, "The sleeper" demonstrates what the critical writings only assert--that the death of a beautiful woman is the most poetical topic. Because his concept of supernal

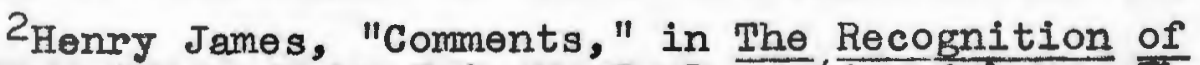
Edgar Allan Poe, ed. by Eric W. Carlson (Ann Arbor: The University of Michigen Press, 1970), p. 66. 
beauty addressed itself to otherworldiy loveliness, Poe found little delight in the reflection of nature. In "The Poetic Principle" he comments that "...this mere repetition is not poetry." While Coleridge was concerned with telling the reader about experiences, Poe concentrated on showing the supernal world through the poems. This concept of supernal beauty is inherent in the poems. Chapter II will explore the concept of beauty in detail while subsequent chapters will deal with certain poems in terms of this theory. Contrary to Bate's assertion that Poe did not clarify his choice of words, it is obvious that Poe carefully chose those terms which came as close as possible to indicating concretely what was for him an intuitive experience. Being as much a scholar of the language as a technician employed in the rhythmical use of it, Poe was certainly aware of the connotations implied by his word choices. It can hardly be denied that the poet who so painstakingly created poetic pyramids such as "The Raven," "Vlalume," "Israfel," and "To Helen" made certain decisions with respect to lexicon and idiomatic use of words and phrases before he employed them. The mester nit picker who derided his contemporaries over the use and mis-use of grammar was most certainly careful to avoid exposing himself to literary broadsides by committing the egregious errors for which he took others to task. The mathematical precision with which Edgar Poe proceeded in the rhythmical creation of his verse and prose writings is so obvious as 
to make Bate's disinterested derision laughable. Basing his study evidently on "The Poetic Principle," Bate stoops to call Poe's "general critical outlook...mainly significant as one of the more extreme examples of a romantic tendency of thought." Citing Poe's theory which posits the imagination as the "'soul' of poetry," Bate attempts to make the reader believe that Poe's use of the word "imagination" is vague when viewed in contrast to the definition employed by Hazlitt or Coleridge.3 It is interesting to note that no textual evidence is given to shore up this feeble observation. Coleridge, as we know, separated the imagination from fancy. His concept of imagination was then divided into primary and secondary considerations. The primary imagination was defined as "the living Power and prime Agent of all human Perception" and the secondary as "an echo of the former."14 By contrast, Poe's concept of imagination, which endeared him to the French symbolists, hinged on a perceptual distortion of reality in order to get to a higher reality. In essence, Poe's concept of the imagination is the broader of the two since Coleridge has, as Poe says, "imprisoned his own conceptions by the barrier he has erected against those of others." Coleridge was able to integrate beauty

3Walter Jackson Bate, "Edgar Allan Poe," in Criticism: The Major Texts, ed. by W. J. Bate (New York: Harcourt Brace Jovanovich, Inc., 1970), pp. 351-52.

4Samuel Taylor Coleridge, "Imagination," ibid., p. 387. 5 "Letter to Mr. Poetry and Selected Criticism of Edgar "Allan Poe, Allen Tate (New York: The New American Library, 1968), p. 152. 
with truth whereas for Poe the two ideals were at odds.

Perhaps the most outrageous attack from Bate's quarter comes in his assertion that Poe sought to "narrow the word 'poetry' until it suggested merely short, lyric verse, or even isolated lines of verse." He goes on to use that statement as a staging from which to deny Poe his claim to any measure of conterporaneity whatsoever. 6

Certainly no solecist, Poe is more likely to tell us what poetry is not and what is not poetry thus leaving an entire world consisting of poetry rather then to narrow down the word "poetry." His tendency to expand the art form to its widest dimensions is the very opposite of Bate's contention that his writings tend to narrow the definition of poetry. Poe's well known contention that the universe was the poetic composition of the Supreme Being is indicative of his expansive definition of poetry. If Poe applied a limitation to poetry it most surely was his self-imposed dedication to the American tradition of lyric poetry. But Poe evidently saw poetry as more than just pooms--for him pootry was also a cosmology.

There are, certainly, those among us who would violently disagree with Dr. Bate. If the poet ever lived who sought to expend not only the word or the concept but the being of poetry to its $n^{\text {th }}$ degree, then without doubt, that poet was Edgar Allan Poe. 
Unfortunately, Bate's casual dismissal in a page and one-half introduction to his critical writing, is perhaps the least of the slanderous essays dealing with Poe. That many of the titans in American and world literature should become positively or negatively polarized with respect to $P O \theta$ is at once puzzling and yet strangely gratifying. This is not to say that Bate is an example of the modern Poe critic. Admittedly, his approach is somewhat harsh. Yot, his acid pen is somewhat typical of the critic who vented his critical wrath on Poe.

Based on an all too literal dictionary-in-hand reading of Poe's three main bodies of critical writing, Yvor Winters succeeded in creating a sort of bookish carnival in which one is entitled to have, for his literary quarter, three strikes at Poe. Applying what he has misread of Poo's critical work to a few selected poems, Winters is able remarkably enough to construct his "heresy" that "...E. A. Poo, although he achieved, as his admirers have claimed, a remarkable agreement between his theory and practice, is exceptionally bad in both."7 This thesis will show that besides achieving "remarkable agreement" between theory and practice, Poo created valid and extraordinarily sensitive art as well as painfully honest critieal work.

7Yvor Winters, "Edgar Allan Poe: A Crisis in the History of American Obscurantism, " in Recognition, 1970, pp. 176-77. 
Misunderstood as his writings are, his foelings with regard to imagination and reality are even more rarely grasped. His ideals of transcending earthly rationality and coming to the great spiritual awakening in the supernal realm are easily taken at less then their true worth. Dealing with Poe's uncompromising position with respect to the real, i.e. anti-poetic world, Roy Harvey Pearce says:

Driven to want to leave that world behind for the one he could create, he set himself apart from Emerson and his other major contemporaries. Poe had to grant an absolute disjunction between the world of common sense and the world of the imagination. The others were by and large concerned in the name of man, to see the two worlds as one.8

Poe's addiction to the ethereal--his hellish struggle to heare the psyche to the very edge of the imaginative wilderness--is in large measure the exact center of his genius. The projection of the imagination to that furthest point imaginable and the artist's curious desire to begin his creations at that point have been responsible (obviously) for the tales and Arthur Gordon Pym as well as his supernally hyper-active poetic writings. Through the use of the most gossamer of threads, Poe constructed an incredibly delicate intellectual structure having as its foundation that inherent thirsting after the supernally beautiful. Intentionally constructing

$8_{\text {Roy Harvey Pearce, The Continuity of American }}$ Poetry (Princeton: Princeton University Press, 1961), P. 144. 
his intellectual stepladder to fall short of the goal, Poe posits the personal philosophy that final and complete attainment of the supernal is not possible in the realm of consciousness we, of needs, deal with on this side of the grave. By placing the forbidden fruit just out of reach, the tantalizing insufficiency of man is justly portrayod. That Poe, who wrote the rule book, was equally unable to attain the unattainable--to reach the unreachable--is the self-contained definition of his artistic torment. His human failure to hold on to the pleasures of the next world is shown in an expression of grief "at our inability to grasp now wholly, here on earth, at once and forever, those divine and rapturous joys, of which through the poem, or through the music, we attain to but brief and indeterminate glimpses." Poe was certainly able to pull himself and his readers to the brink of the next world; to catch a glimpse of the beauty there reigning and to aid us in achioving the same, but, of course, being mortal (though paychically sentient) he was unable to capture the supermal experience for more than a fleeting instant. The ephemeral, transitory nature of these journeys to the world of aesthetic perfection was sufficient cause within itself to produce the melancholy mood which is necessary to even its fleeting success. Seeing then, the briefest moment of exposure to p. 160.

9"The Pootic Principle," in Complete Pootry, 
the supernaliy beautiful as an aesthetic success of the first order, the poet might well concentrate his efforts on perfecting that path to success which worked for him. Poe's numerous reworkings of the poems is proof of his personal application to the task.

Recognizing that one's imagination might at any time be surpassed by any other individual, Poe through constant revision of his works never stagnated nor allowed himself to be satisfied with his attempt through literary art to reach the supernal state. Writing in "Marginelia," he humors himself and the reader with the figure of a youngster bettering the imagination of the author of "Jack and the Beanstalk" by Imagining with no more apparent effort than any other youthful endeavor to triple the height of the menacing giant. ${ }^{10}$ Poe's point here, quite obviously, is that the child's boundless imagination is a desirable trait for the supermal quester to develop. Because of the poetic quality of his prose writings, the problems which we would expect with regard to the application of his aesthetic to the fields of poetry and prose are somewhat less formidable than they might otherwise be.

The United States produced few enough celebrated artists during the nineteenth century without their

10 "Marginalia," in Pooms of Edgar Allan Poe, od. by Dwight Macdonald (New York: Thomas Y. CroweII Co., 1965). p. 163. 
spreading their talents too thinly. There are few, for instance, who would make the claim that Melville's verse is the equal of his prose fiction. Poo was singular in this respect. Appreciated in the European manner, which was applied to the fullness of one's artistic worth and not to one particular forte, he was dealt with on the continent not as a critic, or a poet, or a writer of talos, but as an artist whose ability was great in all these areas as well as the area of cryptography for which the Europeans held a great admiration. If we might adopt the European standard and deal with Poe as an artist in the round--a sculptured artist, not a painted one--we have the sort of foundation upon which we can quite readily construct the superstructure of our own American genius in much the same manner as that used by Valery and Baudelaire (though admittedly the latter's fascination with Poo was based on far more than aesthetic considerations).

Knowing as we do that the writing of verse was Poe's primary passion and the writing of mechanical critiques of his contemporaries was born of commercial necessity, we might suspect that he would abandon the poetic form in his prose and hurriedly scramble back to his own ground and apply himself to the writing of some very valuable verses (if the slap at Henry James might be allowed). Quite the contrary was the case, however. Poe seemed content to turn out some of the most poetic of American 
prose.

"Ligeia" (the short story) might easily be considered as much a poem as "Ligeia" (the poem from "Al Aaraaf"). All of Poe's known necessities are present in the tale. There is, for instance, an oplate heightening within the person of the narrator. We have of course, the death of a beautiful woman, the establishment of melancholy as the prevalent mood and a third variable-the unreliable narrator. Making use then of the subject matter best suited to his poetry and the "most legitimate of all poetical tones," Poe had for all practical purposes written a poem. The catch, obviously, is that he had perfectly disguised this poem behind the diaphanous facade of the short prose tale.

In dealing with his aesthetic philosophy, we have little choice but to draw on all available writings. While this sort of approach would be hardly appropriate for many other authors, it is a.good deal less incongruous in a study of Poo's work. Applying as he did his pootic principle to all of his writings--poetry and prose, Poe left a carefully trimmed but incredibly rich collection of written works.

Unwilling to leave his theories in the form presented in "The Poetic Principle," Poe showed the reader the path to supernal beauty and informed him of the danger of being overly nearsighted in dealing with literature in one 
of his lesser known tales.

The degree of control which we can exercise over the focusing of the inner eye is, I contend, the key to poe's aesthetic theory isasmuch as that theory addresses itself to the problems with regard to the worlds of imagination and reality. Poe, who truly loved to indulge in oryptography and hidden meanings, showed us the way to an understanding of his world in an oft-neglected tale (a tale Incidentally, which is as much a poem in its own right as any verse produced by the same author), namely "The Sphinx." The narrator of this tale like our bookish critics has been seated before a window reading. He lifts his eyes at length from the volume to the window before him but fails to adjust his focal length and due to this error is unable to see through the window. His inner mind set on seeing no further than the printed page, he struggles with the words there presented rather than with the twin worlds they represent in the volume. Mistaking a tiny insect on the window for a huge monster on the landscape beyond, the narrator is a sickeningly accurate symbol for the critic. The literalistic reader referred to above is holistically metaphorical for the human failure to adjust one's inner eye or consciousness to the focus necessary to see beyond common sense reality to that world of the imagination in which a greater reality of fancy is present. Of course, this superimposition does indeed, as Roy Harvey Pearce suggests, lead to the creation of "... a series of 
manic oxymorons..."Il but it is precisely this sort of juxtaposition of apparent contradictions which gives rise to the non-rational state of mind which, in turm, is so necessary to the achievement of the supermal state. No matter how seemingly confused; no matter how hazy, Poe exercised complete control. That control, so painstakingly exercised over the consciousness of the poet, must be understood by the reader if the supernal state is to be attained. Dealing with this phenomenon of contradiction as expressed in "Dream-Land," Richard Wilbur states, "Poe's strategy here is analogous to that of the Zen Buddhist who contemplates a logical contradiction in hopes of shortcircuiting the intellect and so inviting a mystic illumination. "12

Poe developed a personal philosophy which created an inner tension in which his intellectual faculties were matched against the aesthetic extremes of his hyperactive imagination. Through the mental turmoll thus induced, he was able to achieve the same sense of confusion with regard to sensory awareness of reality or unreality that the opium-influenced mind might experience. By introducing so many of his narrators and personae as opium smokers or alcoholics (as in "Ligeia," and "Hop Frog"), Poo makes

${ }^{11}$ Pearce, Continuity, p. 152.

${ }^{12}$ Richard Wilbur, "Introduction," in Poe, ed. by Richard Wilbur (New York: Dell Publishing Co., 1959), p. 36 . 
their sensory distortion more believable.

In summary, it can be noted that the two sides of Poe's artistic character--the mathematically precise and the artistically free--have combined to form some of the finest poetry ever produced. The extent to which conscious focus influenced the work can only be speculated upon. In attempting to honor Poe's own critical guidelines the biographical approach must bo avoided.

This thesis deals with Edgar Allan Poe's most important artistic work, his poetry. Poe's passion was for the creation of poetry, and it is in this area that he exceeds the best efforts of his contemporaries. It is unfortunate but, nevertheless, true that the vast majority of critics have ignored the poems in order to concentrate on the excitement of the tales. His short stories in no way compromise the aesthetic ideals elucidated in the poems. The poems, on the other hand, give a great deal (in terms of awareness of aesthetic stimuli) to the tales.

Wallace Stevens has said poetry helps us to live our lives. Poe goes beyond this and creates poems which deal with spiritual life. A strong believer in the inmortality of the mind, Poe had a unique view of death. Viewing death as merely the passing of our physical beings, he could not help feeling that the mind (the soul) would be in a better situation liberated from worldly realities. He found his rest in poesy. Our undertaking here is the 
nearly classical search for Atman, Brahman, Kairos--terms which admittedly Poe did not use but terms with which he could hardly be unfamiliar given his obvious (though possibly cursory) knowledge of Eastern scripture.

Edgar Allan Poo's major contribution was his poetry. Through his poetic work, Poe will lead us to the summit of superhuman existence. The following chapters deal with the theory and selected poems in terms of that theory. 


\section{II}

\section{SUPERNAL BEAUTY}

The spiritual, intuitive world of dream-like softness--more nebulous, more ethereal than we can readily Imagine--1s the very definition of the realm of the supernal. This imprescriptible realm which offers an alternative to the world of cause and effect reality furnishes the sensitive soul with a supra-reality in which one's own inner light is the basis of one's perceptions.

The realm of the supernal, as we shall see in our exemination of "The Sleeper," is one in which beauty may reign eternally without fear of being tainted by the appetites of the anti-poetic world. And since Poe, perhaps more than the mafority of artists, was concerned with this sort of beauty, it is not at all surprising that he leans towards the intuitive world beyond and away from the world of cause and effect reality--his own sort of reality coming alive only in that aesthetic realm which resists the pressures and falsities of the real world. Poe establishes then, the world of supra-reality as the only reality. In writing of the elevation to that world through poetry, Poe states:

That pleasure which is at once the most intense, the most elevating, and the most pure, is, I believe, found in the contemplation of the beautiful. When, Indeed, men speak of Beauty, they mean, precisely, not a quality, as is supposed, but an effect--they refer, in short, just to that intense and pure elevation of soul--not of intellect, or of heart--upon which I have 
comented, and which is experienced in consequence of contemplating "the beautiful." Now I designate Beauty as the province of the poem, merely because it is an obvious rule of Art that effects should be made to spring from direct causes--that objects should be attained through means best adapted for their attainment--no one as yet having been weak enough to deny that the peculiar elevation alluded to is most readily attained in the poem. I

The world of the supernal is available to us only insofar as the artist constructs for us a spiritual springboard by means of which we are able to execute the necessary transcendental leap and aspire to that level where exists the supernally beautiful. The poem being uniquely suited to act as elevating agent, it is little wonder that $P \circ e$ constantly sought to refine and rework his art into the most nearly perfect verse imaginable.

Poe's idea of achieving supermal beauty through the poem is evident in certain characteristic methods. These include the use of surprise, artistic transcendence through the metaphor of sleep or death, and music (the rhythmical creation of beauty). These three methods will be dealt with at length as subsequent chapters investigate the poems. The method of surprise (as used in "The Bells") indicates that Poe was aware of the effectiveness of the unusual. According to Poe's philosophy, surprise is useful in shocking the reader out of the common rationality, thus freeing the soul to be more perceptive toward the supernal.

l"The Philosophy of Composition," in Poems of Edgar Allan Poe, p. Il9. 
Perfectionist though he was with respect to absolute correctness in poetic form, Edgar Poe realized the benefit to be gained through inclusion of the totally unexpected. As shall become evident in the examination of the specific poems, the element of surprise--the shock of sudden elevation--is inevitable in Poe's work. The extent to which the surprise is augmented or diminished in intensity is left entirely to the poet. Never one to ignore the extraordinary, Poe was possessed of an unusual awareness of the outré and was uncommonly fond of precipitating his singular interest in his poetic work. His instinctive aversion to being trapped into artistic sterility through slavish adherence to poetic principles, manifested itself rather marvelously in his intentionally fractured rhyme schemes. "The Sleeper" may be perceived of on a certain lovel as an exercise in visual rhyme. But consider the artistic spanner in the works: "All Beauty sleepsl--And lod where lies/Irene, with her Destiniesd"

The eye, catching the end of a verse, whether long or short, expected, for the ear, a rhyme. The great element of unexpectedness was not dreamed of--that is to say, of novelty--of originality. "But," says Lord Bacon, (how justly!) "there is no exquisite beauty without some strangeness in the proportions." Take away this element of strangeness--of unexpectedness-of novelty--of originality--call it what we will-and all that is ethereal in loveliness is lost at once. We lose--we miss the unknown--the vague--the uncomprehended, because offered before we have time to examine and comprehend. We lose, in short, all that assimilates the beauty of earth with what we dream of the beauty of Heaven.

$$
2 \text { "Marginalia," ibid., p. } 153 .
$$


The element of surprise functions in a different manner from other methods Poe uses to approach the supernal world. Operating somewhat like a literary sauna, the unexpected allows the reader to drift through the steamy womb-like warmth of the poem's form until suddenly he is plunged into the icy pool of novelty. When given the opportunity to carefully analyze certain effects used in poetry, the most analytical minds will become lost in method and tend to lose sight of the intended end of the art. By being surprised with the "unexpectedness" of a certain effect, the reader cannot fail to rely on immediate responses rather than on well though out reactions. The response to the beauty demonstrated by the poet would thus be emotional rather than intellectual.

Another method which he used to a great extent is the idea of sleep and death as a metaphor for transcendence. Since sleep and death both perform a symbolic destruction of the real world, Poe finds the freedom to work within this context concentrating on the mind and soul divorced from the physical world. The dream, quite obviously one of his very favorite metaphors, was used to fine advantage in "A Dream," "Dream-Land," "Dreams," "A Dream within a Dream" and, of course, "The Sleeper." Closely related to the sleep/death method is the notion of the hypnotic or mesmeric effect on the consciousness. That to deal with the especial powers of the 
oft-neglected soul of man, one must, of necessity, wipe the mind blank of considerations which affect the physical body is, naturally, obvious. Poe's interest in hypnotism (or mesmerism as it was then called) provided him with better psychic equipment than the majority of his contemporaries. Predating by more than a century the psychedelic art movement, Poe was sufficiently aware of the electrical power of man's psyche to use his knowledge and conjecture in this area to help in the formulation of what anyone with a taste for such things must surely recognize as the definitive poetic statement concerned with this part of the human experience. In "Mesmeric Revelation," Poe states:

Whatever doubt may still envelop the rationale of mesmerism, its startling facts are now almost universally admitted. Of these latter, those who doubt, are your mere doubters by profession--an unprofitable and disreputable tribe. There can be no more absolute waste of time then the attempt to prove, at the present day, that men, by mere exercise of will, can so impress his fellow, as to cast him into an abnormal condition, in which the phenomena resemble very closely those of death, or at least resemble them more nearly than they do the phenomena of any other normal condition within our cognizance; that, while in this state, the person so impressed employs only with effort, and then feebly, the external organs of sense, yet perceives, with keenly refined perception, and through channels supposed unknow, matters beyond the scope of the physical organs; that, moreover, his intellectual faculties are wonderfully exalted and invigorated; that his sympathies with the person so impressing him are profound; and, finally, that his susceptibility to the impression increases with its frequency, while, in the same proportion, the peculiar phenomena elicited are more extended and more pronounced. 3

3Edgar Allan Poe, "Mesmeric Revelation," in The Complete Tales and Poems of Edgar Allan Poe, ed. by Hervey Allon (New York: The Modern IIbrary, 1965), p. 88. 
Awareness, then, we might safely say, of the largely unexplored powers of the psyche was a major forte in Poe's literary bag of tricks. His consciousness of the beauty projected by the pure soul without interference or tainting by the vulgarities of physicel necessities, led him to the brink of man's fullest measure of existence. At this point, it follows, man must either strike up some sort of deal with his own faculties in relationship to the universe or take upon himself the extensive psychic responsibilities of becoming his own god.

A third method is the use of the power of music. "The Bells" and "Israfel" are excellent examples of Poe's musicality. Poe states, "music, when combined with a pleasurable idea, is poetry." Thus, since pleasure is the proper end of the poem, and since the concept of supernal beauty is intimately connected to the pleasure of ethereal experience, the use of music completes the work and fulfills the requirements of poetry. Chapters III and $V$ will discuss in some detail this area of music and musicality in the poems.

Obviously, these three are not the only techniques Poo uses to attain to the supernal realm. Certainly, the brevity of the lyric poem, exotic sense imagery, and the internal focus required of the reader are important as methods of reaching through poetry to the supernal. It is also important that the reader recognize that Edgar Poe's 
poetic philosophy is not easily segmented. Most often we will find that Poo uses the various methods enumerated in combinations. For example, "The Bells" combines the hypnotic trance-like effect with the power of music and rhythm. It is through this layering of techniques that Poe creates in the reader the desired effect. Needless to say, the notion of mysticism which he exposed himself to in the reading of the Koran and other Easterm scriptures and philosophical writings, pervaded a goodly number of his poems in greater or lesser degrees of obviousness. The delicate softness which so often accompanies his verse is rarely directly attributable to one poetic convention or another. More often than not, Poe offers us a glimpse of the symmetrical whole he has created through the fitting together of the appropriate effects in their proper measure. While mysticism, narcosis, mesmerism, music, and vertigo play their respective parts in selected poems, the poet's success in achieving his nearly flawless verse is attributable to none of these individually.

When faced with the universal challenge--when we come, at length, to the sort of awareness Poe has been attemptine to show us--are we still articulate as human beings or are we reduced to bodiless spirits? Poe's answer is quick. The only way in which we can achieve everlasting rapture is, obviously, through leaving this mortal life. The grave offers us a whole new world of pleasure as may be 
seen in our forthcoming examination of "The Sleeper." In the meantime we can, through fine art, approach the supernal world and catch momentary glimpses thereof. The hedonist in each of us is invited to indulge itself in pleasure feasts of short duration. In the event that the soul becomes addicted to supernal beauty to the extent that living in the real world becomes impossible, the only welcomed escape is death. The conqueror worm which deals only with the flesh and bone of the deceased excites no concern in the mind. Of course, it requires little in the way of effort to reach beyond the grave after one has actually died. The trick is to have the best of both worlds--to hold on to the mortal life while exposing one's soul to the world beyond. The desperate struggle for Nirvana-the striving to lightly touch the misty unreality of the imaginative world--is Poe's self-contained contest. That boundless place where his spirit met and mingled with Baudelaire's, that altar of beauty bejond the gateway of death, is the very region where all living minds escape from the deceased physical bodies and merge. With the universal consciousness. When all souls become one with God, as Poe suggests in "Eureka," they all become (at least in part) the Supreme Being. As each becomes a part of the whole, so does the whole diffuse itself among the several parts. Man, reaching for immortality, finds escape from the temporal nature of his existence through the fusion of his 
consciousness with that of the Creator. "Each soul is, in part, its own God--1ts own Creator." Speaking of the diffusion of the self amongst the Universe, Poe holds that man finds his identity in that of the Supreme Being. He states that man "...ceasing imperceptibly to feel himself Man, will at length attain that awfully triumphant opoch when he shall recognize his existence as that of Jehovah. "th Poe's philosophy of man's place in the universe then, obviously, held that man, being as much or as little as a pore in the palm of God's hand, could find his identity only in the mergence of all souls into the very being of the creator. In essence, man becomes his own god by virtue of being a part of that whole which he knows as God.

This integration of mortal and immortal energies, of necessity, combines the most and least desirable aspects of each-and integrates these in a new perceptive force capable of that which the individual members are not. It is in this state--seeing through the eyes of God as well as through our own--that we are most capable of heightened perception. Our utilization of these newly acquired perceptive tools is, perhaps, imperfect jet the glimpse of eternity we are capable of perceiving while in this state makes the effort worthwhile. By rising above the boundaries

4Poe, "Eureka," in The Works of Edgar Allan Poe, ed. by Edmund Clarence Stedman and George Edward Woodberry, IX (New York: Charles Scribner's Sons, 1914), pp. 166, 168-69. 
of our mortal sight, we automatically waive our human right to worldly satisfaction. The pursuit of happiness becomes, for the individual so admitted to the presence of the eternally beautiful, a passion into which are hurled the full creative energies of his being. The relationship of other worldly happiness to the excitement of poetry becomes somewhat less incongruous in light of Poo's contention in "The Poetic Principle" that the proper end of poetry is pleasure and that poetry itself is the "Rhythmical Creation of Beauty." Since pleasure, i.e. happiness, is the desired end of the poem, it follows that the pursuit of happiness through the channels of the poem would excite the poet's sensitivities in the process.

With me poetry has been not a purpose, but a passion; And the passions should be held in reverence; they must not--they cannot at will be excited with an eye to the paltry compensations, or the more paltry commendations, of mankind. 5

Poe holds that by applying the passions rather than the rational thought processes, man can ultimately achieve that end--supernal beauty. One must abandon every thought of charting his progress or of dealing in any fashion with what in any case is an ethereal abstraction.

Perceiving of the supernal quest as an inherent thirsting in the soul of man, Poe saw the desire for knowledge of the next world as an outward symbol of man's Jearning for the spiritual. In "The Poetic Principle,"

$$
5 \text { "Preface to the Poems," ibid., p. } 887 .
$$


he states:

We have still a thirst unquenchable... This thirst belongs to the immortality of Man. It is at once a consequence and an indication of his perennial existence. It is the desire of the moth for the star. It is no mere appreciation of the Beauty before us--but a wild effort to reach the Beauty above. Inspired by an ecstatic prescience of the glories beyond the grave, we struggle, by multiform combinations among the things and thoughts of Time, to attain a portion of that Loveliness whose very elements, perhaps, appertain to eternity alone.6

The apparent problems inherent in achieving spiritual goals within the technical framework of the poetic form did not exist in any great degree for Poe. Fer from allowing himself to be stretched, on the literary rack, between the demends of technical perfection and the sweet calling of the world beyond, Poo was the master of reconciliation between the two incompatible forces. Rather than play the one against the other, Poe constructed a kind of poetic monument in which the strength of the one shored up the weaknesses of the other and vice versa. That he encountered no insurmountable problem in the integration of the delicate with the harsh is remarkable in itself and an accomplishment we might otherwise tend to doubt were the poet not the incredible Edgar Poe.

This extraordinary elevation, this exquisite delicacy, this accent of immortality which Edgar Poe demands of the Muse, far from making him less attentive to the technique of execution, have impelled him constantly to sharpen his genius as a technician.7

6"The Pootic Principle," ibid., pp. 893-94.

${ }^{7}$ Charles Baudelaire, "New Notes on Edgar Poe," in Recognition, 1970, pp. 57-8. 
The major characteristics of Poe's concept of supernal beauty are as difficult to enumerate as the wonders of heaven. Clearly, some sort of transcendence is central to his philosophy, but to be specific with regard to the absolute starting point and the dimensions of the desired goal requires a very false kind of pragmatism. "Sharpness and fullness of meaning are, in Poe's theory, incompatible with poetry. "8 Nevertheless, certain observations based on his own writings are possible. Poe, very obviously, concentrated his talent on the breaking down of harsh realities. Sharp corners and flat walls were absolutes which stood between the imagination and pure freedom.

Straining after a supernal beauty which might restore the unity of the diffused universe-ma of his own shattered soul--the poet begins with earthly things, ...subverts their identities and accomplishes their imaginative destruction. The supposition is that a melodious and rhythmic destruction of the earthly must be hearenly.?

The conscious reader of Poe's work cannot be ignorent of his oft-expressed views concerning the end of poetry. The familiarity of the concept that pleasure is the end of the poem and that the corpse of a beautiful woman is the most suitable topic thereof might very generally induce a feeling of contempt. Yet, if an understanding of his concept of beauty is desired, it becomes necessary to survey the

\footnotetext{
8ilbur, "Introduction," in Poe, p. 33.

9Ibid., p. 19.
} 
readily obvious. Poe never gives, in concrete terms, an absolute definition of supernal beauty, but rather indicates in highly intuitive fasion that the end is the pleasure of personal accomplishment in the realm of beauty. What we find in the supernal state is largely personal (directed in great measure by our own individual goals). Poe's contribution is not in providing the perfect aesthetic heaven, but in showing the way in which to accomplish our own desired ends.

In conclusion, it might be stated that Edgar Poo's approach to the supernal state is characterized by certain artistic methods. Stating in "The Poetic Principle," that it is "...en obvious rule of Art that effects should be made to spring as directly as possible from their causes," Poo employed whatever method he saw as most successful in Inducing a hypnagogic state in the reader. The idea of supermal beauty is conveyed, in his poetry, through certain characteristic methods. The more familiar methods, of course, include the death of a beautiful woman, the brevity of the short lyric form and exotic sense imagery. There exist, however, certain other significant (though generally less familiar) methods. As this chapter indicates, these are the method of aesthetic shock or surprise, the metaphor of sleep and death, the uses of music both as metaphor and as the "rhythmical creation of beauty," and an ordering of the reader's internal focus on the poem. The purpose 
of this scholarly investigation into Poe's concept of ethereal beauty is to reconcile the theory with the poetry through the use of three representative poems. In the following chapters certain techniques are discussed as they relate to transcendence to the supermal state in the individual poems. "The Bells" serves as an exposition of the technique of artistic transcendence through the effect of hypnagogic rhythms while "The Sleeper" accomplishes the same end through the death of a beautiful woman and "Israfel" through the power of music. The concept of interior focus which requires a concentrated application of the reader's sentient abilities to the poems, is dealt with at some length in Chapter III and further amplified in subsequent chapters. 
THE HYPNOTIC STATE AS A ROUTE TO THE SUPERNAL IN

\section{"THE BELLS"}

"The Bells" is a particularly enlightening addition to Poe's writings on supernal beauty. The use of the hypnotic effect of the incessently clanging bells is rather successful as an avenue of approach to the ethereal. While a strict critical analysis of the poem would doubtless turn up a staggering amount of technical information concerning the construction of the work, it would be largely wasted material since the aspect of Poe's work investigated in this thesis is not concerned with the specifics of "The Rationale of Verse." The intensity of the elevating experience is the main item of interest for the purposes of this examination. An investigation of this elevation and the effects used to stimulate the heightening of the "moi interieur, the pure visionary self"l is dependent largely on the mood of the poem rather than on the specifics of construction. This is not to deny the importance of the well-balanced, careful construction of the poem. Obviously, it is this sort of absolute order which holds together the less concrete aspects of the work. Since there is an unsettled feeling to the supermal subject matter of the poem, it is only the style and format of the work that roots the poem in worldly reality. Concentrating

$$
\text { IWilbur, "Introduction," in Poe, p. } 20 .
$$


then, only on the form as it directly pertains to the reaching for supernal beauty, this chapter addresses itself to an investigation of what is probably the most nebulous area in Poe's writings--the hypnotic trance-like effect of the bells as an ald in attaining the supernal experience.

A fine example of Poe's integration of his poetry with his aesthetic theories, "The Bells" lends itself particularly well to our concept of focus. Through subtle use of the musical power of the various bells, Poe is able to make that which is not sensuous appear to be sensuous. That is, the metaphor is constructed stanza by stanza until the point is reached where each sound from the bells strikes a definite responsive chord in the soul of the reader. The hypnotic effect of this poem may create, within the mind of the reader, an inner tranquility and express to his soul, insofar as it is expressible, what sort of peaceful serenity awaits him beyond the grave.

The reader is able to experience the physical sensations which occur during the tolling of the giant bells. The sound waves which travel the primary distance between the instrument and the narrator or spokesman and, similarly, the secondary and longer journey between the visible world and the realm of the surreal imagination are broken and bent when they physically contact the human listener. Poe's use of sound within the poem depended largely on his ability to project the audio experience through the use 
of certain literary techniques. It is through the timely use of the onamatopoetic and the somewhat paranoid tone of the sound-saturated narrator that Poe performs the intellectual threshold-crossing ceremony and ushers the reader into the substance of the art, thus simulating the perspective of the narrator. Recalling the theory of sensory focus brought forward in Chapter $I$, the heightening of the consciousness which allows the mind to escape the cacophony of the bells is attributable to proper focus of the senses on a higher world. The break between the real world (or antipoetic) and the world of imagination and art is made complete at such time as the reader finds the deafening sound the premier holder of his interest and not the instrument from which it proceeds. One might safely assume, then, that the break between the two aforementioned worlds is signposted by the separation of cause from effect. The onamatopoetic effect, hypnotically helpful as it is in setting the stage for the search after the supernal, is likewise a stumbling-block which requires a good deal of effort on the reader's part if he wishes to get beyond its spellbinding hold on the consciousness. The conscious effort expended by the artist must be matched by the sensitive reader if he is to be borne up to the lofty perch of the supernal. To be sure, the attainment of the inner heightening is so extraordinary that whatever intellectual labor is done, the end justifies and 
over-compensates for it. When the reader is able to get beyond the onematopoela and breaks as it were the poem's moidenhead, he is thrust into yet another realm of beauty tinged with fear. The sense-stunning tolling of the gient bells successfully bridges the gap between the tolerable and intolerable degrees of beauty. Where one's pain threshold is the aesthetic yardstick, "The Bells" surfaces as the definitive study of this phenomenon.

No stranger to either beauty or pain, Poe was able to assemble an aesthetic stepladder the use of which leads the uninitiated to the crest of supernal beauty. As the average person is unable to focus his inner eye on the supernal initially, the reader must be willing to diligently work at it. Poe has provided a number of signposts along the way. But no promise is made concerning one's degree of success in rising to the level of the supernal. No guaranter provides that the reader will experience the heightening effect--only that this verse or that worked for Poe and that he attempts to share his triumphs with other sensitive souls insorar as his verse might help them achieve similar aesthetic results.

Like the omniscient host in "The Sphinx," Poe is ever ready to point out the error of our ways through the exhibition in his art of the sureness of pace needed to ascend to the ethereal level.

Consideration above and beyond the onamatopoetic 
must be given the incessant clanging of the bells in order to do justice to the poet. In Eastern religious and philosophical thought a good deal of attention is given to the mantra or chant as an aid in forsaking the world of flesh and getting beyond to the pure world of spiritual calm. The clanging of the bells serves a not very different purpose. Through the use of this worldly tool, the reader is given an alternative spiritual path to follow. He can re-create the effect of the bells on the narrator of the poem through reading the work aloud again and again until at length he, like the persona, comes to the point where the nightmarish reverberation of the bells becomes a dream of tinkling music and staggeringly beautiful sensual images. When through repetitive use of the mantra, the reader is $a b l e$ to induce a trance-like state in which he is receptive to the sensual experience of the supernal world, the poet has succeeded inasfar as he is able.

The tension within the poem itself is carefully measured in each stanza. The degree to which it is possible for the tinkling silver bells of stanza one to Induce a psychic leap is limited indeed. As the bells become heavier and more terrifying (golden bells in stanza two, brazen bells in three, and iron bells in four) the attention of the persona moves from the "merriment" and "happiness" of the smaller bells to the "terror" and "solem thought" of the heavier bells. Finally, the persona 
asks himself what sort of sadistic fiend must pull the ropes to cause the incredible racket. The point is, of course, that the more involved the person becomes with the sound of the bells, the less likely he is to concentrate solely on the metallic monsters. Lifting his sensory focus to other objects, the bells recede into the background of his mind until they provide but a musical framework for the new activities of the imagination.

The taste for repeating whole lines and groups of lines, which grew progressively more conspicuous in Poe's verse, may be accounted for in the same ways. To repeat words or lines without (as in the modern sestina or villanelle) continually modifying their meaning is to shift the reader's attention from sense toward sound. If the sound is regular and sonorous, it may prove mildly hypnotic--as Coleridge found by endlessly repeating his own name--and so further the poet's effort to cast a spell.2

Beautiful as the moment of aesthetic breakthrough to the world of anti-reality is, we must in all fairness to the poet investigate further that moment which inevitably precedes the leap--the point of departure. While this point of departure is different in each poem it is invariably a violent, sudden shock. The consciousness is never fully able to absorb the impact of an immediate ascent into an unknown spiritual sphere. The reader's initiation into the world of intuitive idealism is never subtle in Poe's art. The poet, who is prescient to some degree with respect to the world bejond, is able to guide the reader and set him 
aright during the course of the journey but is unable (or perhaps unwilling) to soften the blow of the experience-beyond-experience upon the entranced soul of the reader. In "The Bells," the point at which the narrator loses sight of the giant bells as his instrument of torture and enters a trance-like state of music and sensuous beauty is the highest moment of the poem. While only the briefest of glimpses into the world of the supernal is permitted, the moment of spiritual exhilaration experienced by the narrator (and hopefully the reader) is the guide by which the sensitive soul will continue to lead his life.

The stepping-off places in the individual poems are nearly as intangible as the realm of the supernal, but it is possible to make some observations with regard to the probable points of departure. Quite obviously, the precise moment of revelation will vary from individual to individual.

The point at which the word "bells" is repeated until it no longer bears any sort of relevance to the iron instruments but is an entity unto itself, being no symbol for an object of reality, but rather becoming a combination of consonant and vowel sounds possessing a claim to its own reality, is one of the more important places where the spirit might hope to be lifted from the rational world to the next.

To the rolling of the bells-of the bells, bells, bells--

To the toling of the bells-- 
of the bells, bells, bells, bells,

Bells, bells, bells--

To the moaning and the groaning of the bells.

As the poem progresses from stanza to stanza, the poet lessens the steepness of the supernal hill by lengthening the number of final lines which end with the word "bells." Stanza one ends thus in its three final lines; stanza two in its final four; stanza three with five and stanza four with six. Never a shoddy workman, Poe shored up his literery stepladder in such a fashion in order to aid the reader in achieving the final victory--a glimpse of the supernal world.

A second place where the bells might well trigger a spiritual response is in stanza four:

What a world of solemn thought their monody compels!

In the silence of the night,

How we shiver with affright

At the melancholy menace of their toned

The establishing of the "solemn thought" and the setting of the melancholy mood are rather inclusive of the necessary ingredients to reach the supernal level. Again it becomes evident just how perfectly structured Poe's work is. The precision is directed towards helping the reader see beyond the rationality of the real world. Specifically, the melancholic solemnity introduced in this stanza mesmerizes the senses through terror and, at the same time, creates the mood Poe found most suitable for poetry. Having thus atisfied the logical demands of the poetic form while 
simultaneously shocking and numbing the mind, the poem provides a very direct path to a certain sort of aesthetic achievement.

Needless to say, the methods listed here are at best an abbreviated number of ways in which the poem in question can provide for the spiritual ascension of the reader. Obviously, there are as many approaches as there are individuals. While certain people will respond more favorably than others to Poe's efforts and will achieve more in the way of ethereal experience, Poe suffers none of his readers to fail utterly in the search. Covering his approach from all angles, the master allows even for failure to include certain elements of success since failure could not but induce a feeling of melancholy in the sensitive soul and since melancholy is the most appropriate mood in which to approach the supreme happiness.

A very important method of attaining to the supernal state, as envisaged by Poe, is through the use of music and musical imagery. The musical power of Poe's poetry is rather extraordinary--his use of higher spiritual harmonies being unequaled in modern literature. There is evidence both from Poe's life and from critical writings which show his interest in the power of music. The poet whose wife was an accomplished singer and who accompanied her on the flute was obviously aware of the power of music and of its idiomatic correctness in any search after supernal beauty. The intangible, indefinite pleasure which is the desirable 
end of art suggested to the poet the ethereal qualities of music. By making music inherent in his poems, Poe created a multi-faceted art form in which more of our sensory apparatus is called into action. His ability to trigger this sort of action is proof of at least partial success in this area. His poetry, through the incorporation of feolings and rhythms more usually reserved to musical compositions, achieves a somewhat higher validity on the scale of exquisiteness in art.

Integrating the emotional loveliness of music with the mathematical precision of unerring poetic format and tempering the resulting product with a great deal of spiritual calm, the poet created a dynamic art which escapes the iron-clad dungeon of drab uniformity in a manner not unlike that utilized by our consciousness in spiralling upward toward aesthetic enrichment.

A poem, in my opinion, is opposed to a work of science by having, for its immediate object, pleasure, not truth; to romance, by having for its object an indefinite instead of a definite pleasure, being a poem only so far as this object is attained: romance presenting perceptible images with definite, poetry with indefinite sensations, to which end music is an essential, since the comprehension of sweet sound is our most indefinite conception. Music, when combined with a pleasurable idea, is poetry; music without an idea is simply music; the idea without the music is prose from its very definitiveness. 3

In searching after the "fearful symmetry" of the eternal loveliness, Poe was unwilling to reduce the full 
offect of music on the soul. The joys beyond the grave being the goal of inmortal man, the most natural transportation was on the soaring lines of vibrating music--the vibrations of the instrument or voice being perfectly in tune with the soul of the poet.

Contenting myself with the certainty that Music, in its various modes of metre, rhythm, and rhyme, is of so vast a moment in Poetry as never to be wisely rejected-is so vitally important an adjunct, that he is simply silly who declines its assistance, I will not now pause to maintain its absolute essentiality. It is in Music, perhaps, that the soul most nearly attains the great end for which, when inspired by the Poetic Sentiment, it struggles--the creation of supernal Beauty. It may be, indeed, that here this sublime end is, now and then, attained in fact. We are often made to feel, with a shivering delight, that from an earthly harp are stricken notes which cannot have been unfamiliar to the angels. 4

According to Poe's theory, the sympathetic droning of the sirens of the supernal complements and supplements our feeling of drifting and swirling in the thick delicious air of that state which is our goal. Utilizing the beauty of music as a catalyst in our transcending these mortal boundaries, we cannot but attune ourselves, for an indescribable moment, to the ethereal level of semi-consciousness we desire to attain. By synchronizing the rhythms of the poetry with those of the mind, Poe sought to simplify the flight to the supernal world. Offering little in the way of intellectual perceptions, the poet does make clear, in the poem and more particularly in "Eureka," certain 
intuitive harmonies between man and the universe, thus closing the existing gap for a moment. Poe's use of music was to add a more spiritual note to the poem through the orchestration of existing harmonies. The intuitive perceptions experienced by the conscious reader are as carefully constructed as they are spiritually frail.

Since the rhythms of poetry derive in great part from the characteristic rhythms of the emotions, the supraemotional nature of Poe's poetry would be sufficient explanation for its frequent metronomic regularity. One could also confidently attribute the regular rhythms (as well as the heavy assonance, alliteration, and rhyme) to Poe's desire to approximate music (the vaguest, hence most spiritual of the arts), and to secure the magical advantages of incantation. 5

When the horror of the bells' monstrous noise gives way to the rapture which accompanies the sensing of supreme beauty, it is not at all unlikely that our freed consciousness, soaring throughout the universe, will perceive of the bell's tones as more dulcet than even the quivering lute strings of the angel Israfel.

The importance of "The Bells" to a full comprehension of Poe's concept of supernal beauty can barely be overstated. It is altogether possible that, like the sweet musical strains from the world beyond, the tinkling of the bells beckons us to a higher level of understanding. It is probable that certain other poems will lift us higher still but without that first step, no endless journey is possible. Through affording us the opportunity to gain some

5wilbur, ibid., p. 38 . 
sort of sensory perspective, the poem exorcises a number of spiritual stumbling blocks. It is as a literary blueprint that the poem achieves its great worth. With each stanza of the work, we shift aesthetic gears, as it were, until we find ourselves in a sort of spiritual overdrive wherein the tinkling, chiming "clangor of the bells" motamorphizes into a melancholy ecstasy. In no poem does Poe more firmly take the adventurous reader by the hand and lead him step by step, stanza by stanza, to a revelation of the glories and ecstasies beyond the mortal existence. If Poe offered mankind a course in spiritual fulfillment, "The Bells" would, no doubt, be lesson number one. The guidance and mode of aesthetic delivery presented in "The Bells" must be inwardly and thoroughly digested before a fuller exploration of the supernal experience can be undertaken. 


\section{IV}

\section{"THE SLEEPER"}

"The Sleoper" is ideally suited as a starting point in evaluating that aspect of Poe's concept of supernal beauty in which he investigates the related states of sleep and death. Death, something of a common subject for poets, carries a particular significance for Poe. Representing the perfect peace and tranquility which comes after the world of the flesh, death is a welcome solace to the aesthetic quester. His stereoscopic viewing of death and sleep is consistent with his idea (expressed in "The Colloquy of Monos and Una") that "By sleep and its world alone is Death imaged."

Perhaps requiring an extra-sensory sort of appreciation, "The Sleeper" demands the full attention of the reader's resources. The ethereal calm is re-emphasized by the lack of literary rigidity. Between the worlds of the living and the dead. We float on the supernal sea of joy. "The sleeper" is, perhaps, the poem most likely to be misinterpreted on the sensory level. The reader might tend for example, to mistake the shroud of dewy vapor for a deliberate though shadowy obstacle on the road to Beauty. But on the contrary, the dimly outlined figures and nonfigures only add to the necessary confusion which creates for us this floating neither-here-nor-there feeling. 
an exposition in verse of a certain aspect of Poo's feelings about death, namely the time of peaceful sleep which ensues directly after the moment of death and before the great blackness.

The "sleeper" is a dead woman laid out in her grave-clothes. She is in that condition of somnolence which Poe describes elsewhere--in "Spirits of the Dead" or "The Colloquy of Monos and Una"--as the initial state of consclousness after "death." The landscape of the poem sympathizes with her intermediate condition: the moon sheds its opiate influence on drowsy flowers (which are symbols of remembrance and purity); a ruin settles but does not yet "plunge"; a lake forgets the world in hypnagogic trance. 1

The narrator of the poem, however, is unable, in the final analysis, to waken the dead. The poet is very familiar with the world of dreams, having devoted a few very fine poems and certain tales to that strange state. Making use of the world of dreams as a figure for the world of the supernal, Poe is able to struggle with the poetic and real variables and come to grips with certain less than evident truths with regard to the divisions (real and imagined) between the worlds of reality and fancy.

I have been happy, though in a dream. I have been happy--and I love the theme-Dreams in their vivid coloring of life, As in that fleeting, shadowy, misty strife

of semblance with reality, which brings

To the delirious eye more lovely things

Of Paradise and Love--and all our own-Than young Hope in his sunniest hour hath known.?

Poe's involvement with a sort of opiate-like

I Wilbur, "Notes," in Poe, p. 136.
2"Dreams," in The Works of Edgar Allan Poe, ed. by

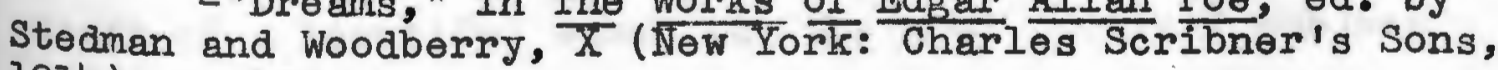
1914 ), p. 127 . 
intellectual dreaming is evidenced again and again in his pootry. Having jettisoned our mortal trappings and joining Poe in the search for the ethereal beauty beyond. the limits of consciousness, we all assume god-like roles which free us of worldly things. The dreaming, drifting, carefree feeling which he seeks to establish in certain poems is, of course, necessary to an understanding of his unique aesthetic position.

When we attempt to reconcile dreaminess and the concept of focus as advanced in Chapter I, we are more or less obliged to encompass the whole scope of unsureness. The only choice, finally, is to be either sucked into the maelstrom of the sensual sterility or to ascend into the boundless infinity of the supernal. But as surely as proper focus is a prerequisite for clear sight and insight so must the effort precede the ultimate victory. Needed is the energy from within the soul which supplies the fuel burned by the sensitive enquiring mind. We are forced then either to accept the dream world as real or to reduce the real world to dream-like proportions in order to develop the appropriate intellectual environment from which to pursue Beauty of the supernal order.

Granted the above mentioned premise, it follows that sleep, dreams, and death are among the most nearly perfect subjects for Poe's purposes. Poe's constant use of these variables and his well-known insistence that the death of a beautiful woman was the most poetical subject 
matter indicate that we are at least following the proper approach to an understanding of this area of concern. Poe's ability to shift the balance of values is visibly displayed in this poem. The assigning of values usually associated with sleep to the restful grave is a case in point. The poet's insistence that death is perhaps a more desirable state than sleep is exposing his philosophy with regard to this world and that beyond. Obviously, the tortured soul of the artist who won but Iittle in the way of literary honor in his own time must surely have felt that the great sleep from which we never wake would be comforting indeod.

Sleep, the natural habitat of dreams, is not an unusual topic for the poet who lived for the spiritual dream--the realm beyond this mundane existence. The author of "A Dream within a Dream," "Dreams," "A Dream," and "Dream-Land"--the same gentleman who likewise was not unfamiliar with the dream-like states induced by laudanum and alcohol--did little to disguise his interest in this area of semi-consciousness.

I stand amid the roar of a surf-tormented shore, And I hold within my hand Grains of the golden sand-How few yet how they creep Through my fingers to the deep, While I weep--while I weep! 0 Godl can I not grasp Them with a tighter clasp? 0 Godl can I not save One from the pitiless wave? 
Is all that we see or seem

But a dream within a dream?3

For Poe, we might say, the grave promised a

release from the torment of the mortal world. In the fashioning of his fortress of beauty, Poe was forced to make use of what worldly tools he possessed. Using his artistic imagination as the cormerstone, his concept of supernal beauty as the building bricks and his aesthetic theories as the mortar, he constructed a monument which weathers not at all and survives to this day--the poems. In this particular poem, the slumbering soul experiences a rebirth into a world where physical excess cannot be initiated--where the cares of the body are irrelevant to the extreme happiness. Dreaming dreams and thinking thoughts which only the angels are allowed to dwell upon, the dead lady inhabits the peaceful realm much coveted by Poe. Using the woman's supposed experiences in the grave as his touchstone in the world beyond, Poe's sympathetic feeling for the dead results in a prayer for her eternal peace.

The lady sleeps I Oh, may her sleep, Which is enduring, so be deep! Heaven have her in its sacred keep! This chamber changed for one more holy, This bed for one more melancholy, I pray to God that she may lie Forever with unopened eye, While the pale sheeted ghosts go by!

Assuming that satori can only be achieved after

3"A Dream within a Dream," in Works, p. 131. 
the cares of the physical world have been forgotten, we are obliged to seek our aesthetic breakthrough either after death or while in the imitation death state--sleep. As dreams take over our entire consciousness when asleep, so does the mind apply itself to other pursuits in like manner. If we are denied the comforts of the grave we must seek our solace either in the state of sleep or through some sort of artificially produced psychomimetic state. It is not in the least surprising then that these two counterfeit deaths are greatly favored by Poe in the poems.

In visions of the dark night

I have dreamed of joy departed, But a waking dream of life and light

Hath left me broken-hearted. 4

Since the conqueror worm holds terror only for the mind which is still associated with a functioning physical body, the worms in "The Sleeper" are not at all horrible monsters but some kind of passive jeweled entity which shares the earth with the dead (or, more correctly, which shares its earth with the trespassing corpse). Helminthiasis, then, being deprived of its terror, the poet is free to exploit the figure of the worm as a poetic convention divorced from its usual connotation as underground demon feeding on the defenseless bodies of the deceased. The same worms which the living fear are the

$$
4 \text { "A Dream," ibid., p. } 135 .
$$


only companions of the living mind within the dead body of the poem's subject. The worms are nothing save the lovely lady's handmaidens of the coffin. Serving a decorative function rather than its usual place in the hierarchy of nature, the worm mentioned in the poem creops softly about the corpse posing no threat whatsoever to the perfect peace of the grave.

When in stanza one Poe speaks of "a conscious slumber," he indulges himself in his fondness for multiple meanings. This phrase can obviously be interpreted as a slumber of the consciousness-a sleep wherein the mind is shut off. On the other hand it can easily be interpreted as referring to a slumber which is conscious as opposed to unconscious--a sleep which relexes the body but allows the mind to soar free. The familiarity with Poe that is gained from his work points to the latter interpretation. However, we would be sady mistaken to reduce Poe to a level of relative simplicity.

Poe's long-standing belief as expressed in "The Conversation of Eiros and Charmion" and "The Colloquy of Monos and Una," that the consciousness outlives the physical shell it inhabits on this world for such a fleeting ingtant, is indicative of a deeper belief in nourishing a mind bound for immortality. Seeing death and its artificial counterparts as softer and more relaxed than the cruel worldly life, Poe grew to possess an uncommon fondness for the dream world where boundaries tended to 
be nebulous; where time and place were without meaning; where the necessities of life were abandoned and the only appetite was that of the mind--one joyfully satisfied in the studying of supernally oriented philosophy. Satisfied then, that the grave offered only solace and not horror, Poe viewed death as a welcome friend. In his tales of grave-related terror, the dead never fear the coffin--it remains for the physically alive to be fearful of the demise of the body. "The Facts in the Case of M. Valdemar" may be perfectly applied in this area. The mesmerized mind of M. Valdemar, outliving the dead body, is greatly relieved to pass to the next world. Poe's attitude toward the world of dreams was hardly different.

Yes! though that long dream were of hopeless sorrow, 'Twere better than the cold reality of waking life, to him whose heart must be, And hath been still, upon the lovely earth, A chaos of deep passion, from his birth. 5

It is extremely easy to be misled by this sort of short-sighted examination of the poems and aesthetic philosophy and to come to view Poe's ultimate world of purification as being inherent in the grave. But, of course, it lay far beyond this easily attainable goal. When the poet enquires "Why and what art thou dreaming here?" he expresses more than innocent curiosity. He would be totally and absolutely victorious in terms of 
his aesthotic and spiritual goals if he could have an advisor in the grave pointing out the sweet dreams of the world beyond. The situation he was in was that of the educated artist estimating as closely as possible the joys beyond the grave but never really knowing how fully he had succeeded.

They who dream by day are cognizant of many things which escape those who dream only by night. In their gray visions they obtain glimpses of eternity, and thrill, in waking, to find that they have been upon the verge of the great secret. In snatches, they learn something of the wisdom which is of good, and more of the mere knowledge which is of evil. They penetrate, however, rudderless or compassless into the vast ocean of the "light ineffable," and again, like the adventures of the Nubian geographer, "agressi sunt mare tenebrarum, quid in eo esset exploraturi."

Poe's attention to the trance-like heightened consciousness of the dreamer was evidence of a great interest of his taking form in not only the poems but several tales as well. The introductory paragraph from "Eleonora" quoted above is perhaps Poe's most absolute definition of the sleep state and the ability of the dreamer to pull himself to the "verge of the great secret." The sleeper in this poem is in an enviable position. She is dead. Since Poe's philosophy led him to believe in the immortality of the mind, the world of death was counted as a place of eternal peace wherein one could think bold and beautiful thoughts. The contradictory nature of the merging moods (melancholy--ecstasy) allows little 
in the way of lexical analysis. Poo's aesthetic

oxymorons purposefully avoid expressing the usual starkness of reality by being expressive instead of a sort of hazy rationality.

The dizzying logic employed by the narrator of the poem serves as an introduction to the state of confusion which is necessary to understand Poe's confirmation of death as being perhaps more desirable than the transitory state of sleep. Sleep may offer the ever present possibility of an hellish nightmare. Death, offering only the sweet rest of the next life and dreams of supernal beauty is easily the better choice.

Sleep and dreams being rather important to the aesthetic questing championed by Poe, it is meet that the reader apply considerable of his analytical energies to the exploration of this avenue of approach to the supernal. Poe found a revelation in his dreaming which allowed for a release of the psychic energies he had unleashed through his unorthodox approach to art. His aesthetic hedonism, as pure as it was extreme, led him to the discovery of a suprareality in the darkest corners of the dream world. Richard Wilbur states:

If esse est percipi, as Bishop Berkeley said--if to be is to be perceived--then when we withdraw our attention from the world in somnolence or sleep, the world ceases to be. As our minds move toward sleep, by way of drowsiness and reverie and the hypnagogic state, we escape from consciousness of the world, we escape from awareness of our bodies, and we enter a realm in which reason no longer hampers the play of 
the imagination: we enter the realm of dream.?

The only way in which he could literally make time stand still and achieve the supernal experience for an infinite length of time was to sleep forever or to die. Where the dead sleep-- "All Beauty sleeps!" The eternal sleop to which he ascended in 1849 was an experience Poe was singularly prepared to appreciate. One cannot help but feel assured that in a Baltimore grave "lies Edgar, with his Destinies!"

7Richard Wilbur, "The House of Poe," in Poe--A Collection of Critical Essays, ed. by Robert Regan (Englewood cliffs: Prentice-Hall, Inc., 1967), p. 102. 
ARTISTIC TRANSCENDENCE TO THE SUPERNAL WORLD

IN "ISRAFEL"

Easily the most musical of Poe's verse in both subject and substance, "Israfel" is an artistic monument in terms of its fearsome proportions. By incorporating the element of religion with the beauty we can barely imagine, Poe shows us the point where joy and pleasure meet reverence and melancholy. The moment of spiritual silence, in which all the universe stands quietly, has had superimposed on it the flowing beauty of Israfel's musical improvisations. The spontaneous creation of poetry and the accompaniment of the lute together indicate the source of all internal artistic fire.

In this poem, the concept of interior focus is closely allied to the metaphor of artistic touch. Artistic transcendence through the power of music and the realization of the artistic vision merge at the moment when the touch metaphor is invoked. This combination of techniques is the Poeian method of creating the appropriate effect on the reader. These methods will be discussed in relation to the poem and the supernal experience later in this chapter.

This joyous anthem shows Poe at once happier than at any other time save in those poems having to do with dreams and, at the same time, suitably melancholy at the 
fallure of his earthly environment to inspire song equal to Israfel's. The poet has already placed himself beyond the stars when the poem opens, and he beckons us to follow in the path of giddy happiness by renouncing earthly considerations and focusing our conscious eye on the very heavens.

While Poe insisted on pleasure being the most appropriate end of poetry, we seldom see him as thoroughly immersed in the pleasure principle as within this particular poem. Happiness bordering on euphoria runs rampant throughout the work as the angel Israfeli plays and sings his ecstasies to an audience of stars, moons, plenets, suns and the heightened consciousness of man. The contagious happiness which proceeds from the throat and lute of our star performer engulfs the whole of God's creation in its wondrous warmth, and provides a grand backdrop on which to project the communion of all sensitive souls.

Iike the host of "The Sphinx" (and unlike the guest in the same story) we must close our books, put down our printed poetry and look for our inspiration to the spirit world. The new dawn, the Easter of our souls, is an exciting awakening. The chance to join the choir of angels, if only for the briefest of moments, is synonymous with supreme joy.

The poet's coveting of the position occupied by Israfeli is, perhaps, the most honest moment in his poetry. 
Exchanging the appetite of the flesh for an heightened appetite for spiritual balm, Poe is nearly overtaken with the desire to emulate his angelic hero. To deny the artist's urge to exchange places with the angel would be to deny the artist's very claim to that title. Any poet would, of course, give his very existence in order to achieve anything remotely similar to the position in which resides Israfel. The irony of the situation is that that is exactly what he must do. Poe holds that the worldly life must be shuffled off before existence in the face of the almighty consciousness is possible for any measurable duration of time. A symbolic physical death is necessary to even the brief glimpses since our spiritual desire to attain to that supernal plane negates the physical possession of our earthly being. The infinite goodness of the situation would, obviously, more than compensate for any loss the man could conceivably feel. The singular moment of ascension produced by the poem is that very moment in which the reader is better than dead, better than alive; he is aware.

$$
\text { Humility, rarely an artist's outstanding virtue, }
$$

is nearly lacking altogether in the poet who announces that given the opportunity to trade his existence for that of the angel, he would play with greater boldness.

If I could dwell

Where Israfel

Hath dwelt, and he where $I$, He might not sing so wildly well

A mortal melody, 
While a bolder note than this might swell From my lyre within the sky.

Poe gives himself over completely to the spirit of the poem and, for once, is less the exegete and more the sentimental character than we are often allowed to see. The perfect agreement of heart-felt passion and perfect song is reached by Israfel--an agreement which greatly excites Poe who sees this integration as a greater reality than even he imagined in his critical works wherein he posited the notion that this sort of combination of feeling with art was necessary to an achievement of the supernal realm. Like another American poet of a later century, Wallace Stevens, Poe had a "necessary angel" to deal with who was the person and the idea of Israfel.

The heavenly references, the poem's basis in mythology, and the ecstatic mood served to overcome what one might initially observe as technical mediocrity. As perhaps the most perfect example of poetic passion overtaking poetic reason, this poem is exceeded nowhere in Poe's collected verse. His ability to entertain artistic pleasure at the expense of the usual mathematical precision is encouraging in that it is proof that, at least, his aesthetic ideals have worked for himself. This is not to say that the work is technically poor. On the contrary, "Israfel" has its moments of stunning control. Yet, its grace and beauty seem to extend more from the exalted 
world of imagination than from the realm of reality.

Very neatly supplying himself with a subject which followed directly a notion he had dealt with in "The Poetic Principle," Poe carefully avoided the nearly inevitable downfall in this poem. Israfel is never allowed to merely recite in song the happenings of the real world. Poe's angel holds no mirror up to nature; to Poe's way of thinking none was necessary. Serving as Poe's ideal poet, Israfel combines the sweetness of hearenly music with original stories of happenings in the misty borderland of the conscious mind. It is because of his success in his presentation that the angel arrives at the poetic extremes. Eschewing, as far as possible, the trivialities of the rational world, the angelic bard frees his passions to concentrate fully on feelings having to do with the hugeness of the universe.

He who shall simply sing, with however glowing enthusiasm, or with however vivid a truth of description, of the sights, and sounds, and odors, and colors, and sentiments, which greet him in common with all mankind-he, I say, has yot failed to prove his divine title. There is still a something in the distance which he has been unable to attain. 1

Israfel, whose voice casts a spell over the stars, mesmerizes his audience with the beauty of his music. Even the early morning light halts in its derelopment to listen to the outrageously beautiful tones of the voice and lute.

I"The Poetic Principle," in Complete Teles, p. 893. 
The point of departure from this real world occurs, for the poet, before the work begins and for the reader at such time as he realizes that the summation of all supernal ecstasies is to exist within the soundbox of Israfeli's lute. The swirling music and the incredible reverberation of sound merge and become one with the soul of the seeker. According to Poe, then, man must forsake his Identity and allow his inner harmonies to resonate sympathetically with the strings of the lute. Exploring the intricacies of supernal simplicity, Israfel is in search of the lost chord and of unfamiliar beauty. Bathing in the light of "the red levin," the angel makes good his implied covenant with the ruler of the supernal heavens. This pact is evidently based on a projection into the universal blackness of the vibrating light on which soar the notes produced by Israfel. The lute, then, becomes something more than a stringed instrument. The vibrations resulting from stopping the strings at certain lengths are negligible alongside their more impressive usefullness--the summation of aesthetic experience. The haunting rhythm of the music serves not merely to orchestrate but to become an integral, meaningful part of the universe. Functioning somewhat like the chant in "The Bells," the rhythm of the angel's music provides an alternate path to the ethereal level. The strangeness of the intellectual spiritual pleasure derived from the musical excursions into the unknown is rivalled only 
by the alien sort of enjoyment the listener is filled with on the plane where "deep thoughts are a duty."

But the skies that angel trod, Where deep thoughts are a duty-Where Love's a grown-up God-Where the Houri glances are Imbued with all the beauty Which we worship in a star.

The "deep thoughts" which he mentions in the verse reproduced above are, of course, not intellectual thoughts but passionate expressions of inner feelings. The passions which are released through the resonating lute strings achieve something approaching absolute purity since the strings respond directly to the mood and feelings of the artist whose fingers pluck its strings.

The concept of focus presented in the introduction to this thesis applies here as surely as to the other poems dealt with. The sense which requires precise focusing in this work is the sense of touch. We are told that Israfel owes his artistic success as much to the excellence of his instrument as to any other force--conscious or unconscious. ("That Israfeli's fire/Is owing to that lyre"). We are instructed as to the power of the strings when the poet gives them the quality of life and finds them "unusual" even in this most unusual setting ("The trembling living wire/of those unusual strings"). Poe's interest in the tactile quality of the stringed instrument might well be interpreted as proof of his complete sensuous immersion into the spiritual world. That he used 
as much space of a poem which he had declared must be short to the physical make-up of the lute is interesting. Perhaps his musical background made this point impossible to bypass. But it seems more likely that this was an effort on his part to expose the physical, tangible side of the next world to the reader. Poe related the sensitivity of touch to the concept of supernal beauty.

While it might be argued that nowhere in the poem does the angel literally touch the lute or lyre, it seems rational that Poe might have perceived some sort of harmonic resonance between the heartstrings of the angel and the "trembling living wire" of the physical instrument. of course, it would not necessarily follow that the human admirer (the persona of the poem) would be able to accomplish such a phenomenal feat--the necessity of physical contact then being implied. Since the poet does not attempt to short circuit earthbound rationality in this particular poem, it may be assumed that this metaphorical treatment of the sense of touch (as it relates to the supernal focus) is consistent with the general feeling of the poem.

A point which has long escaped the attention of critics is that (save one place in stanza three where

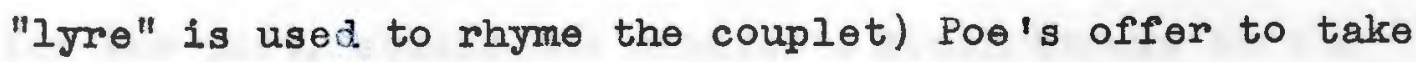
up the position of the angel is a conditional one in terms of choice of instruments. While Israfel (except as noted above) plays the lute--a six to thirteen string guitar-like 
instrument with a soundbox--Poe offers instead to play the lyre--a harp-like instrument the strings of which are not stopped but which are played by plucking the appropriately tuned string.

Poe's attention to the lute as an instrument which is intimately connected to the heart and which is the particular choice of the sensitive musician was a careerlong interest. Roderick Usher's hyper-sensitivity would allow only the sweet tones of the stringed instrument since nearly any other sound would drive him to distraction. Poo's epigraph at the beginning of "The Fall of the House of Usher" is interesting in that it shows beyond a shadow of a doubt that he related the lute to the beating of the human heart in ways above and beyond that suggested in the Koran.

Son cour est un luth suspendu: Sitot quion le touche il resonne.

De Beranger

It can be assumed, on the basis of this evidence from his own writings, that for Poe the artistic touch is the moment of realization of the artistic vision. When the angel touches the instrument, stars stop in the heavens and the moon blushes. It is this sort of word power which, for the poet, equals the painter's brush stroke or the sculptor's chisel blow. Touch being prerequisite to any sort of sound production, it becomes evident that Poe, who was certainly aware of the mechanics of the instrument, would 
hardly deny the physical contact between musican and lute. Music as an emotional outlet is a concept which Poe experienced no difficulty in integrating with his exploration of the sense of touch. Since the chosen instrument is a lute--an instrument which requires two hands to play (one to stop the strings at the appropriate length and the other to pluck them)--Poe has a nearly perfect metaphor for his study of touch as it relates to spiritual achievement through music. Evidently discovering some sort of human inadequacy regarding the sensuousness of touch required to match the lute technique of the omniconscious angel, Poe humbly chose to accept as his instrument a resonating instrument which requires that only the strumming be done by the human hand. By making use of those instruments which respond to the touch of the musician as the harp of AEolus responds to the breezes, Poe incorporates the human element into the spiritual realm as far as is possịble.

The emotions expressed by the supernal musician are those with which the poet deals in his trade--grief, joy, hate and love. Broadcasting these emotions and his reactions to them through the "fervour" of his lute, Israfel creates a psychological music in which the vicissitudes of life are charted on a neatly progranmed map of the intensity and color of his music. By expressing hostility he destroys its potency--by telling of his love he proliferates love. 
Edgar Allan Poe aimed his art bejond the stars. He was remarkably successful in that his work, more than a century after his death, has jet to be appreciated fully. Poe gave us the best possible hints at how to achieve certain aesthetic ends. It is for the reader to take those clues and strive for success in his own direction. Having dealt with this poem and those in the preceding chapters in the manner in which they have been presented, we stand on the brink of the timeless secret. We, like Poe, are "Out of SPACE--out of TIME. $n^{2}$ 
CONCLUSION

After examining in detail one specific aspect of Edgar Allan Poe's aesthetic philosophy and evaluating three selected poems in terms of that theory, an analysis of the concept of aesthetic transcendence to the supermal realm can be undertaken. Poe, obviously, concentrated on the proliferation of the ethereal experience among his readers. Through the use of literary techniques particularly helpful in inducing the intended effect in the reader, Poe was able to make the supernal experience available to others.

The results of this investigation are basically these:

(1) Poe, having formulated an idea about supernal beauty, injected his art with a controlled amount of aesthetic helghtening through which he attempted to show the reader the supernal world.

(2) Through the methods elucidated in Chapter II, Poe sought to create the appropriate effect on the reader thus ushering him to the brink of the supernal realm.

(3) By requiring an interior sensory focus on the poems, Poe set the stage for a perceptual revelation. The careful heightening of the reader's senses is a necessary prerequisite for a glimpse 
of the supernal vision.

The concept of interior focus (introduced in

Chapter I) is based on an ordering of the reader's perceptual abilities in order to achieve a preview of supernal beauty through the poems. The inner eye becomes a sort of symbol for that portion of the imagination which Richard Wilbur has called the visionary self. The importance of seoing with this third eye, thus avoiding the harshness of the physical world, cannot be overemphasized. Obviously, transcendence to the ethereal sphere depends on a clear (though heightened) perception of the quester's aesthetic goals. According to Poe's theory, worldly perception is incongruous to the poem. The poem, existing as it does in the realm of art, owes nothing to the world of truth in Poe's theory. In "The Poetic Principle" Poe says, "he must be theory-mad beyond redemption who...shall still persist in attempting to reconcile the obstinate oils and waters of Poetry and Truth." ${ }^{I}$ Therefore, since the real or anti-poetic world holds little relevance for the poem, it would appear folly of the reader to bring to the poems a sensory focus born of that physical world. In dealing with the several poems, this focus theory proves its worth in a number of places where the polysensuum of the supernal world seems impenetrable. For example, a very clear ordering of the 
audio senses (hearing with the inner ear) is necessary in getting beyond the cacophony of the monstrous bells to the supernal experience. The necessity of regulating strict control over the senses prior to the release into the realm of the imagination becomes obvious in certain areas where the nebulous nature of the poems tends to veil the proportion of reality to unreality.

While the very subject matter limits severely the amount of concrete gain one might reasonably expect from an investigation of this kind, certain conclusions might be readily drawn. Obviously, the concept of supernal beauty was much more than a philosophical thought to Poe. The attainment of that ethereal loveliness became his obsession (perhaps even "monomania" would not be too harsh a term). As the concept was of such supreme importance to the poet, he was driven to an inspired quest after that end in his own artistic work. Through the use of those effects calculated to aid the reader in achieving something on the order of a glimpse of ethereal beauty, Poe used his poetry not only as an exposition in verse form of the aesthetic philosophy he so painstakingly revealed in "The Poetic Principle," but also as a worldly tool which was useful in helping him (and his readers) to attain to that realm of exquisiteness for a brief moment.

To reiterate, Poe's striving for the beauty beyond was a major characteristic of his poetic writings. Of 
course, Poe's poetry suffers little if appreciated on a level altogether divorced of aesthetic considerations. The unfortunate majority of critics and readers read the poem with no eye opened to aesthetic enlargement. But, while the art is strong enough to stand and be considered valid even while denied what is probably its foremost purpose, he who reads the poems and applies them against the critical theories will experience a heightened enjoyment of the art which has been thus injected with a measured amount of hyperaesthesia. Edgar Allan Poo's aesthetic quest through poetry for the ethereal experience of the next world was singularly successful. He becomes the reader's oneirocritic, showing and interpreting through poetry the world of the free imagination. If the reader assumes the appropriate sensory focus and a properly intuitive state of mind, the poems cannot fail. 


\section{BIBLIOGRAPHY}

Bate, Walter Jackson, ed. Criticism: The Major Texts. New York: Harcourt Brace Jovanovich, Inc., 1970.

Bittner, William. Poe--A Biography. Boston: Little, Brown and Company, $19 \overline{9} 2$.

Campbell, Killis. The Mind of Poe and Other Studies. Cambridge: Harvard University Press, $\overline{19} 3 \overline{3}$.

ed. The Poems of Edgar Allan Poe. Boston: Ginn and Company, 1917 .

Carlson, Eric W., ed. The Recognition of Edgar Allan Poe. Ann Arbor: University of Michigan Press, 1970.

Macdonald, Dwight, ed. Poems of Edgar Allan Poe. New York: Thomas $Y$. Crowell Company, 1965.

Pearce, Roy Harvey. The Continuity of American Poetry. Princeton: Princeton University Press, 1961.

Poe, Edgar Allan. Complete Tales and Poems of Edgar Allan Poe. Now York: "Modern Library, 1938.

- Tales of Mystery and Imagination. London: J. M. Dent \& Sons LTD., 1968.

Regan, Robert, ed. Poe--A Collection of Critical Essays. Twentieth Century Views. Englewood cliffs, N. J.: Prentice-Hall, Inc., 1967.

Stedman, Edmund Clarence, and George Edward Woodberry, eds. The Works of Edgar Allan Poe. 10 vols. New York: Charles Scribner's Sons, 1914 .

Stern, Philip Van Doren, ed. Edgar Allan Poe. The Viking Portable Library. New York: The Viking Press, 1945.

Stoddard, R. H., ed. Works of Edgar Allan Poe. 9 vols. New York: A. C. Armstrong and Son, 1884.

Tate, Allen, ed. The Complete poetry and Selected Criticism of Edgar Allan Poe. The Signet Classic Poetry Series. New York: The $\overline{\mathrm{NeW}}$ American Library, 1968.

Whitman, Sarah Helen. Edgar Poe and His Critics. New Brunswick: Rutgers University Press, 1949. 
Wilbur, Richard, ed. Poe. The Laurel Poetry Series. New York: Dell Publishing Co., Inc., 1971.

Woodberry, George E. Edgar Allan Poe. Cambridge: The Riverside Press, 1892. 